\title{
Research the Elements of Entrepreneurial Support Based on Network Relationship Strength
}

\author{
LIU Ying \\ Taiyuan University of Science and Technology, Taiyuan ,Shanxi,P.R.China \\ Email:tykjdxly@163.com
}

\begin{abstract}
The entrepreneurs is the key to decided business success, whose decision is impacted by its environment, especially the impact of entrepreneurial support. Focused support elements which entrepreneurs needs, using the network organization theory method, and the elements of composition as a breakthrough, the paper analysis the elements of entrepreneurial support system and the relationship between the main effects and the mediating effect relationship.
\end{abstract}

Keywords-Entrepreneurial network ; entrepreneurship ; entrepreneurial venture support ;

\section{INTRODUCTION}

With the development of market economy, entrepreneurship is becoming more and more attention. The new venture is the weak economic organization. with the information, the acceleration of technological change and the environmental uncertainty exacerbated, its survival and development put forward higher requirements. New ventures face a lack of resources, market share and many other problems. Network construction can help external resources into the new venture, So the entrepreneur can achieve success, not only is related to the entrepreneurs themselves, but also affected by their environment, especially the influence of entrepreneurial support. In this paper, the network concept is applied to the study of the entrepreneurial support system, the external entrepreneurial support system is as a network organization, the paper focuses on the relationship between the enterprise or entrepreneur network startups, the support required to explore new ventures and mechanism of action.

\section{BASIC CONCEPTS AND THEIR RELATIONS}

\section{A. Elements of Entrepreneurial support system}

Due to the lack of conditions, entrepreneurs will face the enormous pressure of survival, entrepreneurs need to obtain various resources over the network through the most difficult survival period. Birleyetal proposes that In the early days, the entrepreneurs mainly rely on friends, family and acquaintances network to access information. [1]Duchesneau and Gartner [2] (1988) also found that a successful enterprise social relations are more active than the failed enterprise social relations, the success of new ventures often spend more time communicating with partners, customers and suppliers. Burt [3] (1992)thinks there are three kinds of entrepreneurial resources into business during the new enterprise founded, its own financial resources, the entrepreneur's personal ability, and entrepreneurial social resources. The essence of the entrepreneurial network is a selfcentered network (Wassermann \& Faust, 1994; Johannisson, 1998), which is composed of nodes and links .These nodes include the different subjects who contact entrepreneurs or the new enterprises. The network helps entrepreneurs access to information, resources and market. Cai Li (2007) considers that the entrepreneurial environment, including direct and indirect matching environment, which directly match the environment is the entrepreneurial resource supply environment,

Note:The paper is section results by: 1. Soft science of Shanxi province "research on Shanxi cities entrepreneur drive continued ascension mechanism

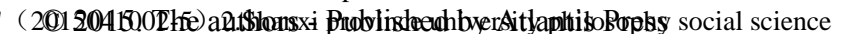
research project" research on entrepreneurship support dynamic fitment based on the theory of the scene". indirect entrepreneurial environment including policies and regulations, intermediary services, marketing, information technology and cultural environment. Cai Li (2011) considers the amount of entrepreneurial resources can not change the entrepreneurial performance, but the ability of integrate resources creates an advantage [4].Entrepreneurship support is the core content of entrepreneurial environment. Lin Song (2010) thinks the entrepreneurial support elements are the external organizations which support the new venture growth Entrepreneurial awareness, entrepreneurship and entrepreneurial networks are the three elements of the entrepreneurship support system. The entrepreneurial support system framework is composed by the spirit of support, resources support and social support to the three elements. spiritual support is "no condition should create conditions ",which answer the question " Why do "; resources support refers to the action of the resources which entrepreneurs depend ,such as university research organizations, laboratories, workstations, and other $\mathrm{R} \& \mathrm{D}$ institutions entrepreneurial support [5,6] and the establishment of cooperative relations, access to financial support, and to obtain the support of the business relationship, personnel support, general legal professional support, resource support to answer the "what"; New Ventures still rely mainly on the contact of individual entrepreneurs access to resources, social is the exchanges or accompany, social support answered the question of "how to do"

\section{B. Network Relationship Strength and entrepreneurial Support Strength}

In all dimensions of the entrepreneurial network, the strength of the relationship is an important dimension. Granovetter thinks that entrepreneurial network strength is the best indicators that reflects the entrepreneurial network. Granovetter proposed the theory of weak ties.Network ties are strong and weak points, which play different roles between people and people, between the individual and the social system ,and among organizations [7, 8]. Wellman \& Wortoley proposed (1990): Strong relationships than weak relations can provide more the types of support. Strong ties than weak ties provide more emotional support, and service support. The key characteristic of the strong relationship is the presence of multiple relationships ( friends, colleagues, classmates, and neighbors). Network members in multiple relationships have a detailed understanding each other, and so better able to provide the support needed by the individual. Nan Lin et al found that the number of multiple strong relationship with personal depressed mood negatively correlated (Lin, 1986).Nan Lin et al found that it is negative correlation between the number of multiple strong relationship and personal emotion low.Aldrich and Woodward (1986) [9] also choose the entrepreneurial network strength as one of the indicators to measure the entrepreneurial network. Arent (1995) [10] preferred entrepreneurial network relationship strength to characterize the entrepreneurial network in the study on the effect of the entrepreneurial network on entrepreneurial performance. 
Umberson (1996) [11] emphasized again the primacy of entrepreneurial network strength in many indicators that characterize the entrepreneurial network links. Gautam (2000) [12] will also be entrepreneurial network strength in the first measure the dimensions of the entrepreneurial network. Rowley (2000) [13] takes the entrepreneurial network strength as an important indicator of the division of entrepreneurial network type. Scott (2002) [14] uses the same the entrepreneurial network strength as one of the four indicators to measure entrepreneurial network. Grootaer (2002) [15] again proposes that the entrepreneurial network is divided into a strong network and weak network based on the strength of the relationship of the entrepreneurial network, Yoo (2003) [16]takes the entrepreneurial network strength as one of the dimensions that characterize the entrepreneurial network in the study of entrepreneurial network related entrepreneurial elements selection . Zhang, Wong (2006) [17] proposed Entrepreneurial network intensity on entrepreneurial network representation and generalization. Burt [18] proposes the entrepreneurial individual can take advantage of the stronger relationship, the greater the likelihood of entrepreneurial success. In summary, various nature of the links among subjects constitute the network, according to Granovetter defined the strength of the relationship, the difference between the strength of the relationship is reflected in the important characteristics of the network links, including the frequency of contact, relationship length, duration, exchange number and reciprocity situation. Strong ties interact more often, feelings of deep and close relationship. Weak ties interact relatively small, relatively distant relationship. Strong ties within the organization plays the role of a link, and the weak relationship between the organizations plays a role of a bridge. Because the strong relationships are often composed of a similar background the individual, whose knowledge structure very similar. similarity is high, which may cause the obtained information and knowledge are redundant and repetitive, but strong relationships is based on trust mode of communication and easier to establish access to high quality information .On the basis of trust, the resource acquired by the strong relationship is very valuable, because most of the key resources information exchange generally occurs only in the high degree of trust between enterprises, weak relationship can not get some key information. But weak relationship exists in different social groups, across the characteristics completely different actors, which can transfer through certain boundary of heterogeneous information. Weak ties can "circle" of people together, and easily carry with innovative new knowledge. So, there is a greater number of weak ties in the network, the resources of access a wider range. In summary, the entrepreneurial network relationship strength reflects the strength of the new businesses or entrepreneurs associated with its entrepreneurial network the main contact,which is an important indicator to measure entrepreneurial network. From the network point of view, the entrepreneurial support system ,that is, the entrepreneurial support network refers to the newly created enterprises or entrepreneurs in order to get all kinds of help, support social networks. All of possible types of Entrepreneurs relationships are divided into spouses, parents, children, siblings, other relatives, superiors, subordinates, business partners, students, friends, neighbors, and other non-relatives, a total of 12 categories. These three kinds of support (spiritual support, material support, and social support) are achieved by entrepreneurs through interaction with other subjects of entrepreneurial support relation in the network. Previous studies have shown that time and frequency, the emotional intensity of the interaction between the entrepreneurs and other subjects, familiar, or the degree of mutual trust, mutual exchange, will affect the strength of the entrepreneurial support.

\section{Ш. RESEARCH METHOD}

\section{A. Research ideas}

This research is that what is the new ventures need support and the entrepreneurial support effect. The following analysis: first, the relevant documents collection and collation of data collection. Second, using interviews to collect the relevant data. Third, factor analysis of relationship, establish model.

\section{B. Research method}

This paper mainly used the personal depth interviews with entrepreneurs to obtain information and data. The beginning of the unstructured questionnaire is basic situation of respondents including the following: age, gender, marital status, level of education, occupation, political affiliation, income. Respondents list the members of the network, and the messages of the top five members :gender, age, education level, political affiliation, marital status, occupation, the unit forms of ownership, income, home address, and respondents close degree. The specific depth personal interviews outline is shown in Table 2-1.

TABLE 2-1

INDIVIDUAL IN-DEPTH INTERVIEW CONTENT AND TARGET LIST

\begin{tabular}{|c|c|c|}
\hline $\begin{array}{c}\text { Intervi } \\
\text { ew } \\
\text { time } \\
\text { and } \\
\text { place }\end{array}$ & Target & The personal depth interviews outline \\
\hline $\begin{array}{c}\text { March, } \\
\text { 2011. - } \\
\text { April, } \\
2011 . \\
\text { Busine } \\
\text { ss } \\
\text { forum }\end{array}$ & $\begin{array}{c}\text { To } \\
\text { underst } \\
\text { and the } \\
\text { impact } \\
\text { of } \\
\text { entrepr } \\
\text { eneurial } \\
\text { success } \\
\text { factors } \\
\text { and } \\
\text { proble } \\
\text { ms }\end{array}$ & $\begin{array}{l}\text { 1.what is entrepreneurship? What factors affect } \\
\text { entrepreneurial to succeed? Where the } \\
\text { entrepreneurial idea comes from? What kind of } \\
\text { preparation before the start? } \\
\text { 2.Do you think where the entrepreneurial } \\
\text { opportunities come from? The main reason for you } \\
\text { to choose or not to choose entrepreneurship? } \\
\text { 3.When you need to make an important decision, } \\
\text { whom to discuss? } \\
\text { 4.What are difficulties in the entrepreneurship? } \\
\text { You will ask whom to help you ? } \\
\text { 5.What should be done by the government? What } \\
\text { is the main way for entrepreneurs understanding th } \\
\text { national policy? } \\
\text { 6.What is the way to obtain the business } \\
\text { knowledge and skills? What is the entrepreneurial } \\
\text { orientation program? Whether the existing } \\
\text { knowledge and skills to meet business needs? } \\
\text { 7.Who would lend to you when you need a large } \\
\text { sum of money? } \\
\text { 8. Whom do you communicate to at least once eacl } \\
\text { month? } \\
\text { 9.with Whom do you participate social activities } \\
\text { (such as invitation to dinner or go to the movies)? }\end{array}$ \\
\hline
\end{tabular}

\section{Data collection and analysis}

\section{A. Data collection}

The article uses a combination of qualitative research "situational analysis" and "Grounded Theory" analysis method. It summarizes the influencing factors and existing problems of the entrepreneurs finally.

1) The paper abstracts 13 concepts through open Login , five small areas, and two areas; 13 concepts are: entrepreneurship, market awareness, business projects, team spirit, entrepreneurial motivation, knowledge, skills, social 
experience, financial support, risks, government support, social relations, relatives, friends, family, Venture effects; Five small areas are moral support, resources support, social support, and the effectiveness of the entrepreneurial support, entrepreneurial support effect; two large areas are the individual level and the overall level.

2) Through the login of association, the paper summarized the 5 small category meaning, discovered some connections: cause or process, the specific number and contact as shown in Table 2-2, Table 2-3 shows:

3) Core-login is abstract processing and analysis, Effect of entrepreneurial support is able to guide the other areas, it can be seen that the causal relationship between the effect of entrepreneurial support and the others(The effectiveness of entrepreneurial support, Spiritual support, Material support, social support) in Table 2-3. Through the login of association, it can be seen that the process relationship between the effectiveness of entrepreneurial support and others(Spiritual support, Material support, social support). The effectiveness of entrepreneurial support is called intermediary relationship category.

TABLE 2-2 THE NUMBER OF CATEGORY

\begin{tabular}{|l|l|l|l|l|l|}
\hline category & $\begin{array}{l}\text { Effect of } \\
\text { entrepre } \\
\text { neurial } \\
\text { support }\end{array}$ & $\begin{array}{l}\text { The } \\
\text { effectiv } \\
\text { eness of } \\
\text { entrepre } \\
\text { neurial } \\
\text { support }\end{array}$ & $\begin{array}{l}\text { Spiri } \\
\text { tual } \\
\text { supp } \\
\text { ort }\end{array}$ & $\begin{array}{l}\text { Material } \\
\text { support }\end{array}$ & $\begin{array}{l}\text { social } \\
\text { support }\end{array}$ \\
\hline number & 1 & 2 & 3 & 4 & \\
\hline
\end{tabular}

\begin{tabular}{|c|c|c|c|c|}
\hline number & 1 & 2 & 3 & 4 \\
\hline 2 & Cause & & & \\
\hline 3 & Cause & Process & & \\
\hline 4 & Cause & Process & Process & \\
\hline 5 & Cause & Process & Process & Process \\
\hline \multicolumn{4}{|c|}{ TABLE 2-3 THE SCOPE OF THE RELATIONSHIP }
\end{tabular}

\section{B. Analysis of relationship between elements}

The AHP is an Effective method to solve the ranking and selection problem with multi-criteria. It uses AHP to further clarify the order of relations among the three areas of the individual level. The basic steps are:

1) Clear evaluation of the program goals, evaluation criteria and evaluation index system

First, a clear assessment of the goal is to get the entrepreneurial support through the establishment of entrepreneurial support system. Second, the structure of evaluation criteria: A total goal is to obtain satisfactory entrepreneurial support. The second layer targets were: B1 is strong relationship support, B2 is weak support ties, B3 is the middle of the state support. P1 :spirit of support; P2: material support; P3: social support.

2) Establish the evaluation model

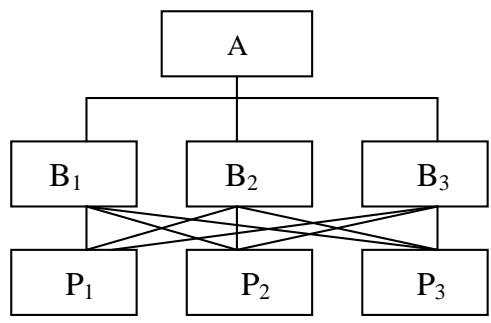

Figure 2-1 hierarchy structure model

\section{3) Judgment matrix}

The paper targets (A) to the highest level for the comparison criteria, compares factors in the target of the intermediate level (B) and constructs a judgment matrix A-B. Similarly, the paper targets ( B) to the highest level for the comparison criteria, compares various factors on the program level, and construct the judgment matrix A-BI, $I=1,2,3$. The various elements of the matrix was rated by entrepreneurs, entrepreneurs friends, and the Government of entrepreneurship etc, the meaning of the scale, as shown in Table 2-4:

\begin{tabular}{|c|c|}
\multicolumn{2}{|c}{ TABLE 2-4 THE NUMBER OF SCALE } \\
\hline scale & Definition \\
\hline 1 & Equally important \\
\hline 3 & Obviously important \\
\hline 5 & Much more important \\
\hline 7 & Extremely important \\
\hline 9 & $\begin{array}{r}\text { The intermediate values of the two } \\
\text { adjacent judgment }\end{array}$ \\
\hline 2.4 .6 .8 & \\
\hline
\end{tabular}

of the following judgment:

4) sort of single level and its consistency test.

6) hierarchy Sort consistency test.

\begin{tabular}{|c|c|c|c|c|}
\hline \multirow[b]{2}{*}{ A-B } & \multirow{2}{*}{\multicolumn{2}{|c|}{$\begin{array}{lll}\mathrm{B}_{1} & \mathrm{~B}_{2} & \mathrm{~B}_{3}\end{array}$}} & $\mathrm{~B}_{1}-\mathrm{P}$ & $\begin{array}{ll}P_{1} & P_{2} \\
P_{3}\end{array}$ \\
\hline & & & \multirow[b]{2}{*}{$\begin{array}{l}p_{1} \\
p_{2} \\
p_{3}\end{array}$} & \multirow[b]{2}{*}{$\begin{array}{ccc}1 & 2 & 3 \\
1 / 2 & 1 & 3 \\
1 / 3 & 1 / 3 & 1\end{array}$} \\
\hline $\begin{array}{l}\mathrm{B}_{1} \\
\mathrm{~B}_{2} \\
\mathrm{~B}_{3}\end{array}$ & $\begin{array}{cc}1 & 3 \\
1 / 3 & 1 \\
1 / 5 & 1 / 3\end{array}$ & $\begin{array}{l}5 \\
3 \\
1\end{array}$ & & \\
\hline
\end{tabular}

( (4) .1.2)

\begin{tabular}{|c|c|}
\hline $\mathrm{B}_{2}-\mathrm{P}$ & $\mathrm{P}_{1} \mathrm{P}_{2} \mathrm{P}_{3}$ \\
\hline $\begin{array}{l}\mathrm{p}_{1} \\
\mathrm{p}_{2} \\
\mathrm{p}_{3}\end{array}$ & 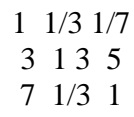 \\
\hline
\end{tabular}

( (4) .1.3)

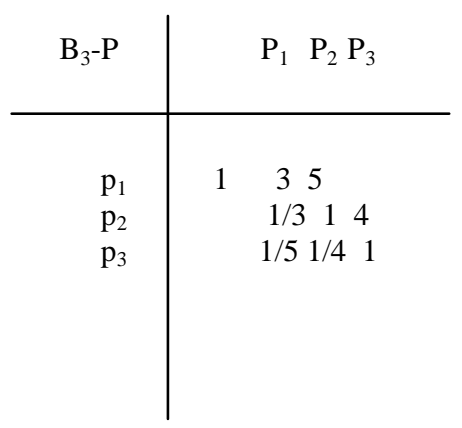

( (4) .1.4) 
Calculation results and analysis are as follows:P1 (the spirit of support) is $0.5013, \mathrm{P} 2$ (material support) is 0.3338 ; P3 (social support) is 0.1649 , important degree of turn in the personal level of the three factors: moral support, material support, social support, they play different roles in the effect of entrepreneurial support. Lin thinks that a weak relationship acts in instrumental work, the strong ties acts in ideographic action. First, the stronger the strength of the network relationship, the more the type of support provided; Second, the stronger the strength of the network relationship, the more likely to provide spiritual support, and the weak ties are more likely to provide material support .

\section{V . ANALYSIS AND INTERPRETATION}

The combination of the relationship strength is an important way to get resources.

\section{A. The strength of relationship based on the resource acquisition process is:}

1) In the early stage of entrepreneurial resources acquisition, entrepreneurial individuals will tend to take advantage of all its network of strong ties, because strong ties emphasize the communication and information between the homogeneity of the members. However, excessive reliance on strong ties, the network will be showing a characteristic path length low-poly high regular network trends, which causes the network search is locked, the entrepreneurial resources can not break the original social network, unable to obtain more competitive resources.

2) With the depth of entrepreneurial activity, entrepreneurial individuals need to break the limited strong ties to obtain more entrepreneurial resources, and need to increase the weak relationship. Weak ties can help to obtain more information, and a lot of entrepreneurial opportunity must be realized through weak ties. But if the entrepreneurial resources acquisition over-reliance on weak ties, the random network will have a trend of the high characteristic path length and the low Class cohesion, which will lead to Internet search in a disordered state, divergence. So the random network Composed completely by the weak relationship is not the final stable state for a personal to obtain resources.

3)According to the principles of economics, these two extreme cases will bring the high cost of local or global network resources, and affect the efficiency of resource access across the network. There is a region between these two extremes, in which can be a local steady state temporarily by the combination of the strength. At the same time, the entrepreneurial network with low path length and high transmission of small world network characteristics exists between the regular networks and random networks.

\section{B. Elements of the system model for supporting new ventures}

In summary, the paper argues that the following relationship exists among the five elements(moral support, material support, social support, and the effectiveness of the entrepreneurial support, entrepreneurial support effect ): First, the main effect of a relationship: moral support, material support, social support, and entrepreneurial support effect exists directly, independent of other variables affect the relationship; the same relationships between the effectiveness of entrepreneurial support and entrepreneurial support effect. The second is Intermediary effect relationships. In short, after the comprehensive building new enterprises support system element model.

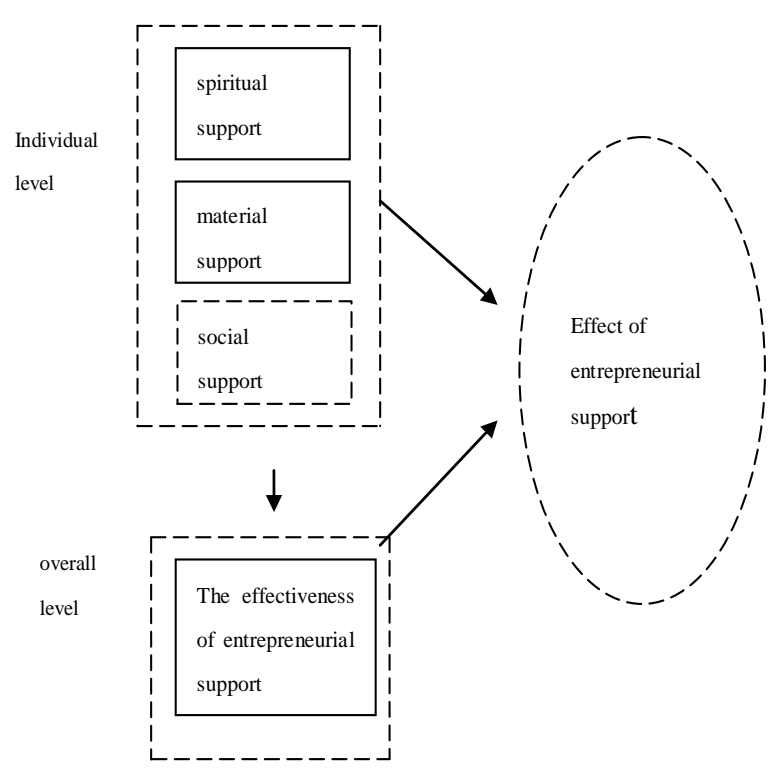

Figure 4-1 Elements of the system model for supporting new ventures

\section{VI.CONCLUSION AND OUTLOOK}

The social network theory is introduced to the entrepreneurial network, Birley [19] and the Ostgaard [20] proposed two basic assumptions: First, the entrepreneurial process is including the process of obtaining scarce resources from the external environment network. These resources include not only financial and other material resources, but also information, ideas, suggestions, opinions and customers. Second, the resources are usually obtained by the entrepreneurial network relationship. In the early days, entrepreneurial network based on individual relationship becomes the main channel for entrepreneurial resources. Late in the entrepreneurial, entrepreneurial network based on commercial relations becomes the main channel for entrepreneurial resources. So, The process of entrepreneurial resources acquisition is to make full use of its network relations, and re-combination process, that is, both the evolution behavior of economic exchange and networking.

From the network perspective: The allocation of resources with the network relationship has a deep soil in contemporary China. Individual choice is not just an exchange acts as a rational "economic man", but also as a rational "social man " choice. Resource acquisition process is through the network to find cooperation partners, when the enterprise has the resource demand. In a certain sense: entrepreneurial firms acquire resources in relation to "early traits the personification of the crystalline stability, commitment, generating a profit organization trade relations among" [21]. The crystallization performance stable organizational relationships for key resources, ways to access resources, which promote the establishment of a new relationship, this series of processes ultimately promote the dynamic change of entrepreneurial network.

From the dynamic point of view: the process of access to resources is that the entrepreneurial individuals based on their own accumulation determine the means by which can get the resources needed, and find the resources to each target node according to their own ability by "network connection". Members of the entrepreneurial network occupy different 
resources, and the flow of these resources in the network is not immediately, but influenced by the factors between network strength and members of the network connection properties.

Entrepreneurial individuals in the entrepreneurial network can be used as network "nodes", who join the network connection independently and autonomous decision-making. The resources search process is ever-expanding network relations and rebuild new or reconstruction of two points between connect an "edge".

When the entrepreneurial individual resource needs generated, entrepreneurial individual start resource acquisition action. According to the entrepreneurial individual differences in different intensity relations of trust, entrepreneurial individuals first select individuals of the resources connected network with strong ties interaction. However, the strong connection between individual resources provided by the species may not be able to meet the individual needs and entrepreneurial resource acquisition cost constraints, entrepreneurial individuals maybe exchange nodes connected by weak ties, after several information exchange activities. At last, entrepreneurial individuals reach an equilibrium in the strength of the relationship based on acquisition costs and resource requirements of classes.

In the entrepreneurial network, members of the strong relationship know each other, Entrepreneurial Network, the strong relationship between network know each other, its internal trust may be more conducive to the acquisition of entrepreneurial resources, and support entrepreneurial individuals gradually completed the transformation from network-based personal feelings to the commercial interests, weak ties have the advantage at this point.Over strong ties make frequent interaction with most of the information tend to be homogeneous and redundant, with the promotion of entrepreneurial activity, strong relationship will make the entrepreneurial resources search into a path lock-in state, resulting in a waste of resources. Weak relations play a positive role in this regard, it can make individuals outside their social circle get advice and support from the large diversity of the collection with positive and relaxed, because there is a big difference, it can deliver more fresh and heterogeneous resources and information. Many entrepreneurs advocates weak ties network is the basis of the entrepreneurial individual behavior, and entrepreneurial individual relationship with weak ties can provide more information than strong ties, these resources and information for entrepreneurial individuals have a positive value. But weak ties may be shortterm and low frequency, it may lead to a larger search costs and risk. In general, the strength of the relationship has advantages and disadvantages during the resource search process. Over-intensive strong ties and weak ties will bring different degrees of negative effects to the resource acquisition, there are different roles in access to entrepreneurial resources based on the strength of the relationship, the reality of the entrepreneurial resource acquisition is to achieve by different strong ties and weak relations constitute "relationship." Uzzi (1997) [22] through empirical research found that only contains the network of strong ties or weak ties reduces the potential to improve organizational performance, the combination of the strength of the relationship between the maximum enhance this potential.

Entrepreneurship support system is an open, ongoing network of matter, energy and information exchange with the external environment. The impact of new enterprises or entrepreneurs based on the web- strength, the paper builds the elements the model of new ventures support, and proposes that there are two kinds of relationships between the elements: the main effect relationship and mediating effect relationship. Role relationship between the main body of the entrepreneurial support system, empirical study of the entrepreneurial support network, different national, regional entrepreneurial support network status in all these need further research direction.

\section{REFERENCES}

[1] BIRLEYS, CROMIE S, MYERS A . Entrepreneurial networks:their emergence in Ireland and overseas [J]. International Small Business Journal, 1991, 9:57-74.

[2] Duchsneau, D .A. , and Gartner, W.B. , A profile of New venture Success and Failure in an Emerging Industry, in Kirchoff, B .A ., (ed.) , Frontiers of Entrepreneruial Research, Babson College, Wellesley, MA, 1988:372-386.

[3] Butt R .Structure Holes:The Social Structure of Competition [M].Harvard University Press: Cambridge, M A, 1992 .

[4] Caili etc. Study on the impact of EO on resource acquisition [J] . Studies in science of science, 2011, (4) :601-609.

[5] Mian S. Assessing value - added contributions of university technology business incubators to tenant firms $[\mathrm{J}]$. Research Policy, 1996, ( 25) : $325-335$.

[6] Bakouros Y L, Mardas D C, Varsakelis N C. Science park, a high tech fantasy?: an analysis of the science parks of Greece [J]. Technovation, 2002, (22) : 123-128.

[7] Granovetter, Mark . Economic action and social structure : the problem of embeddedness [J] .The American Journal of sociology , 1985, 91 (3) :481-510.

[8] Granovetter, Mark. The strength of weak ties [J] .The American Journal of sociology , 1973, 78 (6):1360-1380

[9] Aldrich, H., Rosen , B. , Woodward, B.L. Social Behavior and Entrepreneurial Network [J] . Summarized in Frontiers of Entrepreneurship Reasearch , Wellesley , MA , Center for Entrepreneurship Studies Babson Collage, 1986:239-240.

[10] Arent Greve. Networks and Entrepreneurship an Analysis of Social Relations, Occupational Back ground, and Use of Contacts During the Establishment Process [J], Scand .J.Mamt, 1995, 11 (1) :1-24.

[11] Umberson , D., Chen, M.D. , House, J.S. , Hopkins, K., Slaten, E., The Effect of Social Relationships on Psychology Wellbeing: Are Men and Women Really so Different?[J], American Sociological Review, 1996, 61:837-857.

[12] Gautam Ahuja, Collaboration Networks . Structural Holes, and Innovation : A Longitudinal Study [J] . Administrative Science Quarterly, ABI/INFORM Global, Sep.2000, 45 (3) :425-455.

[13] Rowley T., Behrens D., Krackhardt D. Redundant governance structures :An analysis of structural and relational embeddedness in the steel and semiconductor industries [J] , Strategic Management Journal, 2000, 21 (3) :369-386.

[14] Scott Shane, Daniel Cable. Network Ties, Reputation, and the Financing of New Venture [J] , Management Science. March 2002, 48 (3) :364-381.

[15] [15]Christiaan Grootaert , Thierry Van Bastelaer. The Role of Social Capital in Development: An Empirical Assessment [M/OL], Cambridge University Press, 2002.

[16] Yoo M. , The ties that ( un ) bind: Social networks and entrepreneurship in high technology industries [D], a dissertation submitted in partial fulfillment of the requirements for the degree of doctor of philosophy in the university of Michigan, 2003.

[17] Leung, A., Zhang., J., Wong, P K, Foo, M .D., The use of networks in human resource acquisition for entrepreneurial firms:Multiple "fit"considerations[J].Journal of Business Venturing, 2006, 21 (5): :664-684

[18] [18]Burt R S. Model of network structure [J]. Annual Review of Sociology ,1980,6:79-141.

[19] [19]Birley S. The Role of Networks in the Entrepreneurial Process [J]. Journal of Business Venturing ,1985,1(1):107-117.

[20] [20Ostgarrd T A, Birley S. New Venture Growth and Personal Networks [J]. Journal of Business Research ,1996,36(1):37-50.

[21] [21]Larson A L, Starr J A. A Network Model of Organization Formation [J]. Entrepreneurship: Theory And Practice, 1993,17(2):5-15.

[22] [22]Uzzi B. Social Structure and Competition in Inter-firm Networks: The Paradox of Embeddedness[J]. Administrative Science Quarterly ,1997.42(1): 35-47. 